\title{
TOPICAL ISSUES OF OBJECT AND SUBJECT OF AGE-RELATED PSYCHOLOGY IN MODERN UKRAINIAN REALITY
}

\section{Partyko T. B., Snyadanko I. I., Hrabovska S. L.}

\section{INTRODUCTION}

Successful development of scientific knowledge is stipulated by a clearly delineated area of research which is different from related fields and sciences. This statement is mainly related to those sciences that originated from one source and further on focused on similar issues, for example, psychic genesis. There are different aspects of this issue: anthropogenetic, orthogenetic, epigenetic, phylogenetic, ontogenetic and sociogenetic, while this study focuses on ontogenesis.

Considering origin and establishment of human mental functions in ontogenesis, in Ukraine these issues are studied by experts in developmental psychology. In our country this field of science is also called genetic psychology though it has nothing to do with identification of the role of genotype and environment in formation of individual psychic peculiarities. Impairments of mental and physical development (disontogenesis), especially in childhood, are studied by special psychology.

Age as a unit of analysis appeared in the focus of attention after the publication of L. Vygotsky's work "The Problem of Age", which was written in the 1930s, though it was published 50 years later, to be exact, in $1984^{1}$. After reading this work one can differentiate between the fields of interest of two closely related areas: developmental psychology and age-related psychology. The former studies the genesis of psychic in the whole diversity of this process in ontogenesis, while the latter focuses on peculiarities and regularities of age-related dynamics of psychic in ontogenesis. What will such differentiation of fields mean from the scientific point of view?

First of all, it will enable us to come closer to the crucial solution of the issue about age-related norm of mental development. What is meant is the correct approach to this issue taking into account the fact that the age of a person is the function of both biological and historical time. Thus, there are different dimensions of age: passport, biological, social, cultural

\footnotetext{
${ }^{1}$ Выготский Л. С. Проблема возраста. Собр. соч. в 6 т. Т. 4. Москва : Педагогика, 1984. С. 244-268.
} 
and psychological one. This or that answer regarding correctness of studying age-related norms of mental development does not diminish topicality of studying potential and critical mental capacities in different age-related periods, and does not lessen the importance of identifying those limitations of mental development of a person that are imposed by his/her age. Here comes one more issue that is to be resolved by age-related psychology, which is the issue of age periodization of human life. To resolve this issue one should agree about evidence base that might be used as a criterion for logical passage from one age category to another one.

Thus, interest in object and subject of age-related psychology is scientifically well-grounded. The article is aimed at analyzing approaches to this issue in Ukrainian psychological reality. It should be stressed that the founders of this area of science were such distinguished scholars as I. Sikorsky, M. Lange, V. Zen'kovsky, S. Baley, H. Kostiuk. In Kyiv I. Sikorsky (1842-1919) founded Therapeutic and Pedagogical Institute where they studied childhood-related issues. He was one of the first to start experimental research of performance capabilities of pupils. I. Sikorsky's scientific findings were presented in his monograph "The Soul of a Child" (1901). Well-known Ukrainian-Russian psychologist M. Lange (1858-1921) studied early childhood ("The Soul of a Child During the First Years of Life", 1892). V. Zen'kovsky (1881-1962) became popular after publication of such scientific works as "Children and War" (1916), "The Role of Family in the Life of a Child" (1919), "Psychology of Childhood" (1924), "The Issue of Upbringing in the Light of Christian Anthropology" (1934), etc. The most known works of the Ukrainian-Polish psychologist S. Baley (1885-1952) are "Psychology of the Teenage Period" (1931), "Outline of Psychology in Relation to the Development of Child's Psychic" (1938), "Characterology and Typology of Children and Youth" (1946), "Psychological Problematics of the Teenage Years" (1950). Ukrainian psychologist H. Kostiuk (1899-1982) for almost 40 years chaired Research and Development Institute of Psychology in Kyiv (nowadays - Institute of Psychology named after H. Kostiuk at the National Academy of Pedagogical Sciences of Ukraine), where under his guidance the scholars conducted research on different issues of age-related psychology. The scholar advocated the idea that internal conditions of child's development underwent changes in the process of activity of a child. The driving forces of mental development of a child are inner contradictions between the new content that has to be mastered and the level of cognitive activity already 
achieved. The emphasis was put on the role of education and upbringing in this process ${ }^{2}$. Academic findings of these scholars is the foundation for modern research in the field of age-related psychology in Ukraine.

\section{The object of age psychology: experience of Ukrainian scholars}

It is traditional that every research, especially empirical one, starts from identification of its object. The very notion is interpreted in different ways. If one refers to the comprehensive dictionary of modern psychological terms, then object is defined as "... the fragment of reality onto which the activity of the subject interrelated with it is aimed at"3. Thus, it can be both a person (those, who are studied) and phenomenon (something that is studied). What will be the object of age-related psychology?

The researchers have different ideas about this issue. For instance, M. Savchyn and L. Vasylenko are of the opinion that the object of agerelated psychology should be a person as a subject of self-development ${ }^{4}$. However, a person as an individual who is capable of getting to know the surrounding world and oneself simultaneously is the subject of psychology. Probably, the aforementioned coincidence, when a person as an object of cognition and self-cognition is at the same time a subject of this cognition, shows specificity of modern research in this field. We consider that such integration of object and subject makes the process of identification of psychological problematic of age-related psychology much more complicated in comparison with other fields. Therefore, it is worth considering other opinions on this issue.

R. Pavelkiv ${ }^{5}$ and well-known in Ukraine Russian scholars H. Burmens'ka ${ }^{6}$, I. Kulagina ${ }^{7}$ and L. Obukhova ${ }^{8}$ link the object of this science to the development of psychic (psychic functions, personality) at different stages of life. In this case there are vague boundaries between agerelated psychology and developmental psychology which in Ukraine are traditionally viewed as different applied fields of psychology.

\footnotetext{
${ }^{2}$ Вікова психологія / за ред. Г. С. Костюка. Київ : Радянська школа, 1976. С. 19-20.

${ }^{3}$ Психологічний тлумачний словник найсучасніших термінів / під кер. В. Б. Шапара. Харків : Прапор, 2009. С. 282.

${ }^{4}$ Савчин М. В., Василенко Л. П. Вікова психологія : навчальний посібник. 2-ге вид. Київ : Академвидав, 2009. С. 8.

${ }^{5}$ Павелків Р. В. Вікова психологія : підручник. Київ : Кондор, 2011. С. 6-7.

${ }^{6}$ Психология развития. Словарь / под ред. А. Л. Венгера. Москва : ПЕР СЭ, 2006. С. 25.

${ }^{7}$ Кулагина И. Ю. Возрастная психология (Развитие ребенка от рождения до 17 лет) : учебное пособие. Москва : Изд-во РОУ, 1996. С. 4.

${ }^{8}$ Обухова Л. Ф. Детская психология: теории, факты, проблемы : учебное пособие. Москва : Тривола, 1996. С. 24.
} 
Developmental psychology deals with the issue of origin and establishment of psychic functions of a person, for example, self-consciousness, motives, intellect, etc. Its researches are based upon an important theoretical provision that people are not given ready-made psychic phenomena at birth, but undergo complicated process of establishment under the influence of various external and internal conditions and factors. Here one tries to answer the question about development process while keeping to the most important strategy of this science which is to form a psychic phenomenon. The way of experimental formation of mental processes was for the first time outlined by L. Vygotsky and was called experimental and genetic method. View of the object of research from the positions of psychic functions genesis is also clearly presented in the works by J. Piaget, S. Maksymenko and other scholars.

One of the leading researchers of this issue in Ukraine is the director of the Institute of Psychology named after H. S. Kostiuk at the National Academy of Pedagogical Sciences of Ukraine S. Maksymenko. The fundamental work "Development of Psychic in Ontogenesis" presents the author's concept of personality development in the context of his/her life. Lots of attention is paid to the problem of experimental and genetic method of studying psychic. Specific implementation of this method in the subject of age-related psychology is a forming experiment. "The logic of this method suggests not just simple record of peculiarities of different empirical forms of psychic, but active modeling, their reproduction under particular conditions that enables us to reveal their essence",.

We think that age-related psychology should focus on a slightly different aspect of development which is age-related mental changes. Age is a key notion and major category of national age-related psychology. Interest in the issue of age was first observed in anthropology. In the process of studying traditional societies it was revealed that age and age groups are important structure forming principles of society functioning. Belonging to a certain age group ensures person's rights and duties, determines major social roles and norms of behaviour. The idea of agerelated changes as exclusively biological ones has begun to change. Thus, the notion of age acquired different meaning for understanding the process of development of individual and personal features of a person.

Famous scholar B. Ananjev has established a link between age and biological and historical time and considered age-related changes both

\footnotetext{
${ }^{9}$ Максименко С. Д. Розвиток психіки в онтогенезі. В 2 т. Т. 1 : Теоретико-методологічні пробеми генетичної психології : монографія. Київ : Форум, 2002. С. 291.
} 
ontogenetic and biographical ones. The scholar distinguished two major characteristics of age: metric and topological ones. Metric characteristics are described by the total number of years one has lived. Average life expectancy of the population is the socially important dimension of this characteristic. Topological one is characterized by the stages and periods of various psychic functions establishment which is reflected in human life periodization ${ }^{10}$.

At every age a person has a unique, peculiar only for this period, combination of biological, social, cultural and psychological peculiarities which are not characteristic of any other age period. Classic scholar of global psychology L. Vygotsky made a systemic analysis of psychological age. In his cultural and historical concept the scholar defines psychological age as a unit of analysis of child's development that has its own structure and dynamics ${ }^{11}$. Ukrainian psychologists view psychological age as a relatively closed and qualitatively peculiar chronological stage of ontogenesis. Age determines the degree of psychological maturity of a person: his/her cognitive, emotional, volitional and personality areas and is determined on the basis of correspondence of mental development of an individual (for instance, self-consciousness, intellect, will qualities, emotions, etc.) to the age norm of these indicators for the passport age in question.

To properly understand psychological age it is crucial to understand such notions as psychological new formations, social situation of development and leading activity which are analyzed in details in the work by L. Vygotsky "The Problem of Age"12. Under new formations the author understands those mental and social changes which appear for the first time at a certain age and which influence the development vector of a person. Thus they set a direction of mental development at a certain age and characterize its structure. New formations can be related to the restructuring of the whole mental structure on a new basis, for example, animation complex and formation of individual life of a child under conditions of close bonds with a mother in infants, and also can be related to separate sides of mental development, for example, beginning of arbitrariness of mental processes in early childhood. Psychological new formations become mature at the end of e certain age period. During transition from one age to another psychological structure of age undergoes changes as well. Thus, every psychological age has

\footnotetext{
${ }^{10}$ Ананьев Б. Г. Избранные психологические труды : В 2-х т. Т. 1. Москва, 1970. С. 192.

${ }_{11}^{11}$ Выготский Л. С. Проблема возраста. С. 244-268.

12 Там само. С. 256-258.
} 
specific and unique structure which is peculiar only for this psychological age. In modern Ukrainian psychology psychological new formations in childhood and in the adolescent period are well-researched, while adulthood and elderly age can be characterized by the lack of research.

Age structure is not static and invariable. Changes in new formations and respective development lines in the transition period from one age into another one raise an issue on age dynamics. The structure formed at one age can be transformed into another structure at another age. New age entails new age structure. Eventually it will influence age dynamics. On the basis of age dynamics reflections L. Vygotsky comes to the important conclusion: there is a basic law of age dynamics. The law lies in the fact that development driving forces at a certain age inevitably lead to rejection and destruction of the very basis of development at a given age, marking cancellation of social development situation, end of this epoch of development and transition to the next age $\mathrm{e}^{13}$.

To understand age dynamics one should analyze unique and agespecific system of relationships between a person and social environment which L. Vygotsky called social situation of development. It is a source of mental development and leads to the establishment of age-related new formations, it marks the initial moment of all dynamic mental changes at a specific age period as owing to it social becomes individual. Every age is characterized by its unique social situation of development ${ }^{14}$.

At every age social situation of development has a contradiction that should be resolved through age-specific leading type of activity, i.e. activity when new high-quality formations of personality at a specific age of life are established. Leading activity is characterized by the fact that it allows for restructuring of major mental processes and changes of psychological peculiarities of a personality at a given stage of its development. Change of leading types of activities is a long-time process and precedes given stage of development. For example, for infant age leading activities are direct emotional communication with adults and object and manipulative activity; for teenagers - intimate and personal communication.

Conceptualization of a notion of age made it possible to include it into the objects of research of age-related psychology. Thus, since the 1990s age as a development period and age-related variability of mental phenomena were studied as potential objects of research by

\footnotetext{
${ }^{13}$ Выготский Л. С. Проблема возраста. С. 258-260.

14 там само. С. 258-259.
} 
L. Obukhova ${ }^{15}$ and O. Rybalko ${ }^{16}$. Probably it was too early to discuss it before as it was only in the second half of the previous century when the researchers started paying proper attention not only to the childhood and adolescent period, but also to the age-related changes in adulthood and elderly age. There appeared first generalized data on adult age peculiarities (B. Ananjev, D. Veksler, D. Bromley, N. Baily, V. Ginzburg etc.), where it was proved that adulthood has its own regular changes in mental development. Thus, the academic community managed to overcome stereotypical interpretation of adulthood as an ossification period advocated by Swiss psychologist of the first half of the $20^{\text {th }}$ century E. Claparède (1873-1940).

We fully agree with the opinion that most accurately the task of the modern age-related psychology is represented by the idea where the object is the age-related variability of mental phenomena of a person which is reflected in their dynamics - speed, tempo, duration and direction of mental changes in different periods of life. According to M. Zabrotsky, age-related dynamics of human psychic “... includes studying driving forces of individual development of human psychic, regularities of transition from previous periods to the next ones, from lower stages to the higher ones, finding individual and typological discrepancies in mental development ..., establishment of determining factors" $"$.

O. Rybalko ${ }^{18}$ indicates the following peculiarities of the object of age-related psychology. Depending on the period and stage of life age variability has different intensity and different meaning for a person. At the beginning and at the end of life it is expressed the most. This variability is revealed in unity with individual peculiarities of a person. With age the role of individual mental peculiarities is enhanced, while the role of age-related peculiarities is weakened. In particular, it is characteristic of the adulthood period. In the same way age variability of psychic is revealed in combination with gender peculiarities of a person. In girls (women) and boys (men) similar mental functions at the same stage of age-related development can be formed in a different way. Finally, manifestation of age variability depends on the way of life of a person and real forms of his/her activity. If a person keeps to a lifestyle peculiar for a certain age and is involved in a certain activity,

\footnotetext{
${ }^{15}$ Обухова Л. Ф. Детская психология: теории, факты, проблемы: учебное пособие. С. 25.

${ }^{16}$ Рыбалко Е. Ф. Возрастная и дифференциальная психология: учебное пособие. Ленинград: Изд-во Ленинградского ун-та, 1990. С. 7.

17 Заброцький М. М. Вікова психологія: навчальний посібник. Київ: МАУП, 1998. С. 4-5.

${ }^{18}$ Рыбалко Е. Ф. Возрастная и дифференциальная психология: учебное пособие. С. 7-10.
} 
his/her mental functions will not undergo any age-related changes. It is primarily true about adults and elderly people.

\section{The subject of age-related psychology in the light of key issues and methodological scientific principles}

In general, the subject of psychological research is understood as a part of object which is in the focus of the research. The point is about specific content, quality and regularities of scientific reality the scholar is faced with. Regarding the subject of psychology there has been no consensus among the scholars. In the opinion of the Ukrainian scholar P. Miasojid, "...the subject of psychology is culture-dependent: it is changing throughout historical time, it is enriched owing to the efforts of both single scholars and scientific schools, but still remains incomplete"19. Thus, the subject of age-related psychology cannot be universal, established once and for ever. It is changing and expanding depending on a culture, historical period and most important - on the issues and objectives of the psychological research.

Analysis of the $\mathrm{PhD}$ works, which are topical in Ukrainian environment and which were successfully defended in leading academic institutions in Kyiv for the recent five years (2015-2019), has shown that young psychologists are mainly interested in the topic of adulthood (60\% out of $30 \mathrm{PhDs}$ under analysis). The subject of research is related to personal potential, emotional intellect, stress resistance, inclination to victimity, proneness to conflict and perfectionism, gender and environmental socialization, sense and life orientations and prof essional identity of teenagers and adolescents. Also among the topics are socially resonant responsibility issues, mental and physical health, orphanhood, personality criminalization and migration problems of young generations.

The research is going on in the traditional area for Ukrainian psychologists, i.e. children-oriented topics $(29,4 \%)$. This includes cognitive activity, Self-image, psychological welfare, emotional intellect, feeling of one's own dignity and creative abilities. There are significantly less studies in relation to the adulthood issues $(10,6 \%)$. Ukrainian young scholars are interested in personality spontaneity and crisis of professional establishment in early adulthood, academic self-efficiency of adults in life-long learning, support of public activity and subjective welfare of elderly people. These researches enrich scientific community with new important facts of peculiarities of mental life of modern generation

\footnotetext{
${ }^{19}$ Мясоїд П. А. Загальна психологія : навчальний посібник. Київ: Либідь, 1998. С. 4.
} 
of children, youth and adults, however do not enable us to trace agerelated mental changes.

In this respect it is worth mentioning the work of a famous Ukrainian researcher T. Tytarenko, who among many other publications has an article on age-related dynamics of personal disharmonies $(2004)^{20}$, and $\mathrm{PhD}$ research of the young scholar S. Prakhova on psychological determinants of tackling frustration conditions in pupils of different age groups $(2017)^{21}$.

The classic of Ukrainian psychology H. Kostiuk was of the opinion that the subject of age-related psychology was "...the research of mental development regularities of a person at different stages of his/her individual life or his/her ontogenesis" "22, as well as "... research of driving forces of human psychic individual development, regularities of transition from previous stages ... to the next ones ... individual and typological differences in mental development of children, teenagers and youth, factors that determine these peculiarities" $" 23$.

In modern Ukrainian age-related psychology the subject of research is interpreted in different ways relating it to the regularities of mental development of a person at different stages of his/her ontogenesis (M. Zabrots'kyi ${ }^{24}$, R. Pavelkiv ${ }^{25}$, M. Savchyn and L. Vasylenko ${ }^{26}$ ), agerelated dynamics of psychic, key factors of mental processes development and personality features at different stages of one's life and conditions and mechanisms of personality formation and development (M. Savchyn and L. Vasylenko ${ }^{27}$ ).

Taking into account multi-dimensional approaches, we consider the subject of age-related psychology to be the explanation of psychological peculiarities and regularities of a certain age period of human life and psychological mechanisms of transition from one period to the other. Apart from that a subject of research can be understanding uniqueness of human individuality in different age periods of person's life.

Modern researchers in the field of age-related psychology are faced with a major task to establish a fundamental concept of age-related

\footnotetext{
${ }^{20}$ Титаренко Т. М. Вікова динаміка особистісних дисгармоній. Практична психологія та соичіальна робота. 2004. № 9. С. 67-74.

${ }^{21}$ Прахова С. А. Психологічні детермінанти подолання фрустраційних станів учнів різних вікових груп : дис. ... канд. психол. н. : 19.00.07. Київ, 2017. 241 с.

22 Вікова психологія / за ред. Г. С. Костюка. С. 5.

${ }^{23}$ Там само. С. 6.

24 Заброцький М. М. Вікова психологія : навчальний посібник. Київ : МАУП, 1998. С. 4.

${ }^{25}$ Павелків Р. В. Вікова психологія. С. 6-7.

${ }^{26}$ Савчин М. В., Василенко Л. П. Вікова психологія. С. 8.

${ }^{27}$ Там само. С. 8.
} 
development of a personality in new Ukrainian day-to-day realities. To resolve this major task one needs first of all to conceptually solve a number of topical issues.

The first issue is the problem of causality of age-related mental changes. Here one mainly deals with the issues of preconditions, conditions and factors of age variability of psychic, psychological development mechanisms in every age period, the role of activeness or passiveness of an individual and biological and social aspects in age-related mental changes.

The second problem is related to the chronological order of agerelated mental changes. This problem may be solved within the context of the following theoretical tasks: age-related periodization of human life; correlation of biological, social and psychological age of a person. To solve this problem in the first place one needs to identify regularities of transition from one age period to the next one.

The problem of potential and threshold ability of human psychic in different age periods is the third problem. In relation to this the task is to identify actual and potential abilities of a person in different periods of his/her life, and also age-related restrictions imposed on mental development of a person. What is meant here is a range of normative indicators for different mental fields (personal, cognitive, emotional, willrelated, communicative, etc.) that represent successful mental development in a certain age period. In this respect it is particularly important to identify the role of early age period in further mental development, degree of personal (emotional, motivational, etc.) maturity of a person and boundaries for preserving mental and social activity of elderly people. The problem of potential abilities of human psychic sets the task of theoretical substantiation of age-related norms of mental functions.

The fourth issue is the problem of psychological new formations, central and partial ones, in different age periods. New formations are those mental and social changes that appear for the first time at a certain age and which influence human development vector. It is these formations that determine the age structure. In this respect the task is to research regularities and mechanisms of new formations creation process, their succession, major tendencies and consequences of new formations, agerelated psychological peculiarities that originate from these formations.

The problem of sensitive and critical stages in age-related development of a person is the fifth problem. As early or late influence on psychic in respect to sensitive period can lose its efficacy or have an opposite effect, it is necessary to intensify studies aimed at identification 
of boundaries of these periods considering irregularity and heterochronism of mental development. Due to unclear boundaries of agerelated crises and conflicts with the surrounding world it is necessary to develop diagnostics criteria particularly for age-related crises which should be different from, for example, personal or existential ones, to provide theoretical substantiation for advantages of influence onto human psychic during age-related crisis. Also more attention should be paid to determination of age crises during early, middle and late adulthood.

The sixth problem is the correlation of conscious and unconscious mental manifestations at different age periods. This problem is related to age characteristics of conscious and unconscious motives of performance, formation of automated actions of a person, etc.

The seventh problem deals with gender differentiation. It arises due to different manifestations of age-related variability of psychic depending on gender. There should be differentiation between age-related mental peculiarities of boys and girls, young man and young ladies, men and women. Omission of this issue leads to studying of a person beyond his/her biological sex and, as a result, provokes inaccuracies in psychological characteristics of age peculiarities in the psychic of men and women.

And finally, issue number eight is an issue of correlation of age-related effects and cohort effects. On the one hand, a person always belongs to a certain age group and correspondingly is endowed with typical age peculiarities of this group; on the other hand, this person at the same time represents a certain cohort - generation that who lives under similar social and historical conditions. It is really so that rebelliousness has been characteristic feature of a person in the process of becoming an adult. However, specific content of this maturity will depend on the fact which generation this young person belongs to: whether it is perestroika (transformation period) generation that was growing up in the 1980s under conditions of USSR collapse, or it is the generation of the independent Ukraine who grew up already in the 1990s under conditions of the sovereign state suffering from economic and political crisis. Thus, it is important to differentiate between effects caused by age-related peculiarities and effects caused by generation differences.

Keeping to the following methodological principles promotes resolving the aforementioned problems of age-related psychology: principle of determinism, development principle, principle of historism, principle of consciousness and activity unity, differentiation-integration 
principle, principle of integrity, principle of heredity-variability and stable dynamic imbalance.

According to modern understanding of the determinism principle or causality principle, psychic is formed under the influence of external environment depending on internal conditions of a living being organization: peculiarities of its nervous and endocrine system, abilities, character, etc. In age-related psychology the principle of determinism means that the researcher has to take into account the fact that there can be different influence of external and internal conditions on human psychic and it can depend on the age of a person - passport, biological, social, cultural, psychological one. This principle also suggests selfdetermination that is based on the needs of a person which become a source of his/her activity. Self-determination is a psychological mechanism of volitional regulation of behaviour that is actively formed in the adolescent period and can reach its maturity in adulthood. For example, at an early age children learn to be independent mainly under the influence of external determinants (for instance, parental praise). In the teenage period independence can be reinforced by such an internal factor as a sense of maturity, however due to immaturity of the nervous processes and will efforts this volitional quality in principle cannot be fully formed. And only in adulthood a person can be fully independent and it will be favoured by such internal determinants as positive self-attitude, persistence, determination and critical thinking.

According to the development principle psychic regularities are revealed only in the process of development of a specific person and mankind in general. This principle states the necessity to consider age peculiarities of a person within the context of irreversible quantitative and qualitative mental changes. However, the most important thing is not to record different levels of development, but to explore the transition from one level to the other. Inclusion of this principle into scientific research can be evidenced by correct prognosis of the further development of a certain person.

Mental phenomena can be understood correctly only within the context of historical events which was stressed in the problem of correlation between age-related effects and cohort effects. The principle of historicism states the necessity to analyze age-related mental changes depending on specific social and historical conditions and changes that happen in the history of mankind. 
Having analyzed the findings of foreign researches, H. Laktionova identified different personal features of people belonging to different cohorts. The generation that was born in the 1965-1970s (baby boomers, taking into account birth boom in the US and Western Europe) are prone to hard-work, orientation to stability, thriftiness, diligence. The researcher explains it by the fact that in adolescence they experienced economic problems. Generation born in 1971-1980s was called "Generation X", because their characteristics was significantly different in different researches. Generation of teenagers and youth of postmodern period ("Why?", "What for?", "Next"), born between 1981 and 1993, formulate and try to find the answer to the questions that their peers in previous years did not have, for instance, "Why is it necessary to work, save money, pursue a career?" They are not ready to sacrifice themselves for the sake of work. The researchers explain it by reduction of specific weight of youth in society due to demographic crisis. This generation of young people are very good team workers and communicators, they have well-formed feeling of their own dignity but at the same time they lack self-possession, patience and perseverance ${ }^{28}$.

Thus, to properly understand age variability of human psychic one should study a number of those historical events that mark the way of a certain cohort to adulthood. Therefore, not all the age-related peculiarities identified, for instance, for the cohort of youth or mature people at the beginning of the 20th century, remain unchanged for the corresponding cohort at the beginning of the $21^{\text {st }}$ century. It demonstrates particular importance of historicism principle in the researches of agerelated psychology.

According to the principle of unity of consciousness and activity, consciousness and in a broader meaning - psychic, should be studied not as something abstract and passive but as a process or activity of a real subject. Activity is a condition of emergence and formation factor of human consciousness and psychic. This principle indicates the role leading activity and new psychological formations play in the process of mental development of a person at every age-related stage.

The principle of differentiation and integration views development as something that goes from the state of relative globalism to the state of higher differentiation, hierarchical integration and centralization. As a result of mental structures differentiation global, integral homogeneously

28 Лактіонова Г. М. Учнівська молодь постмодерного часу (за результатами зарубіжних досліджень). Практична психологія та соиіальна робота. 2009. № 5. С. 56-58. 
simple forms are separated and divided into heterogeneously complicated parts, levels and forms. Differentiation may result in full autonomy of psychic function that has been formed, or in establishment of new interrelations among functions, i.e. added complexity of the system. Integration is related to bringing together heterogeneous parts and elements. As a result of integration there is increase in the volume and intensity of interrelations and interactions between the elements, their arrangement and self-organization into a single whole with qualitatively new features. Integration is necessary to create new relations for wider adaptation. In the process of differentiation the structure acquires more specific functions and integration enables new relations that ensure broader adaptation. In the opinion of N. Chuprikova, this principle is one of the most important criteria of the system organization levels, as the level of system organization is evaluated by the number of heterogeneous elements making the system (degree of diversity) and the number of different levels (degree of hierarchy), as well as by the number and diversity of relations among the elements and levels ${ }^{29}$. Thus, differentiation-integration principle can be used as a criterion of psychological age structure development.

Integrity principle shows unity of goals and means of achieving them that is ensured by repeatedness, hierarchy, proportionality and balance of structural elements of the whole. Successful functioning of the system depends on the degree of coordination between system elements. This is an integral functional characteristic of the whole that characterizes unity of goals and means of achieving them. Integrity of the system can serve as a criterion for psychic functions development in a certain age period.

Principle of heredity and variability shows interaction of tendencies to preserve and change as a condition of system development. Preservation tendency is ensured by the genotype that passes down information from generation to generation without distortions, while the tendency to change is observed in variability that manifests itself in adaptation of a certain species to the environment. Genetic program of a person as a representative of Homo Sapiens has not undergone any significant changes throughout recent 40 thousand years, however there was huge progress made in mental development ${ }^{30}$. By studying 3442 persons born within the period from 1889 to 1959 K. Schaie found

\footnotetext{
${ }^{29}$ Чуприкова Н. И. Психология умственного развития: Принцип дифференциации : монография. Москва : Столетие, 1997. 480 с.

${ }^{30}$ Асмолов А. Г. Психология личности: Принципы общепсихологического анализа: монография. Москва: Смысл, 2001. 416 с.
} 
out that indicator of mental abilities of these people showed linear growth according to the date of birth.

The principle of stable dynamic imbalance was for the first time formulated in biology by E. Bauer in 1935. It is the unbalanced state of the system that shows high efficiency of the system and serves as the source of its development, age development including. E. Kniazeva and S. Kurdiumov consider that without instability there is no development. Only imbalanced state of the systems provides spontaneous selforganization and development. Stability and balance means evolution deadlock. These are unstable systems that are capable of self-organization and development ${ }^{31}$. Within the context of age-related psychology this principle was implemented in the concept of bilateral regulation contour by B. Ananjev. Mental processes and features of an individual in ontogenesis are regulated by hierarchical (vertical) and complementary (horizontal or bilateral) regulation system. The scholar considered that in the process of getting more experienced, being trained and with the increase in self-regulation level at the middle age the role of bilateral regulation in ontogenesis is growing ${ }^{32}$.

The aforementioned principles are methodological basis for scientific research on age-related psychology in Ukraine.

\section{CONCLUSIONS}

The issue of object and subject of age-related psychology remains in the focus of modern theoretical researches on age-related psychology. If the object is determined by conceptual understanding of this field and is more general and stable construct, then the subject of research depends on social request to resolve specific issues related to the object of research. Consequently, it means its interpretation should be more flexible. Understanding the subject of age-related psychology research is stipulated by historical, cultural and social facts of the early $21^{\text {st }}$ century that makes it possible to meet the requirements of the period and solve applied scientific tasks. At the same time compliance with principle provisions on object and subject of research streamlines scientific inquiries in agerelated context of research.

Nowadays in Ukraine one should pay more attention to the systemic studies of age-related potential of a person, particularly at the beginning of his/her life (newborns and infants), in middle and elderly age (middle

31 Князева Е. Н., Курдюмов С. П. Законы эволюции и самоорганизации сложных систем: монография. Москва: Наука, 1994. 238 с.

32 Ананьев Б. Г. Человек как предмет познания : монография. Ленинград: ЛГУ, 1968. С. 272. 
and late adulthood). Age peculiarities of these and other age periods described by the scholars of the middle or the second half of the $20^{\text {th }}$ century have to be critically reviewed from the viewpoint of belonging to different generations.

Thus, cohort sequential method could be more widely applied in the researches of Ukrainian psychologists. At the same time attention should be paid not only to the statement of different age-related changes, but also to the regular character of such changes and psychological mechanisms of transition from one age period to the other one in order to build a picture of the integral life journey of a person. Efficient psychological support of the clients also requires understanding uniqueness of the inner world of a person within the context of his/her age-related needs and understanding the reasons and necessity of influence on this person. In this way age-related psychology will contribute to the resolution of tasks which are highly topical in modern Ukrainian reality.

\section{SUMMARY}

The article focuses on different approaches to identification of object and subject of age-related psychology which are studied by modern Ukrainian psychologists. The research outlines the difference between age-related and developmental psychology. It is stated that the key notion and category of this filed should be psychological age of a person. The study substantiates that the object is age variability of psychic phenomena of a person that manifests itself in their dynamics (speed, rate, duration and direction of mental changes in different periods of life). The subject of the research is explanation of mental peculiarities and regularities of a specific age period of human life and psychological mechanisms of transition from one age period to the other one, understanding unique individuality of a person in different stages of his/her age. It is stressed that the object is more general and stable construct, while the subject allows more flexibility in its interpretation. Therefore, the article analyzes key challenges this field of psychology poses for Ukrainian researchers and major methodological grounds theoretical and empirical studies are based on. 


\section{REFERENCES}

1. Выготский Л. С. Проблема возраста. Собр. соч. в 6 т. Т. 4. Москва : Педагогика, 1984. С. 244-268.

2. Вікова психологія / за ред. Г. С. Костюка. Київ : Радянська школа, 1976. С. 5, 19-20.

3. Психологічний тлумачний словник найсучасніших термінів / під кер. В. Б. Шапара. Харків : Прапор, 2009. С. 282.

4. Савчин М. В., Василенко Л. П. Вікова психологія : навчальний посібник. 2-ге вид. Київ : Академвидав, 2009. С. 8.

5. Павелків Р. В. Вікова психологія : підручник. Київ : Кондор, 2011. C. 6-7.

6. Психология развития. Словарь / под ред. А. Л. Венгера. Москва : ПЕР СЭ, 2006. С. 25.

7. Кулагина И. Ю. Возрастная психология (Развитие ребенка от рождения до 17 лет) : учебное пособие. Москва : Изд-во РОУ, 1996. C. 4.

8. Обухова Л. Ф. Детская психология: теории, факты, проблемы : учебное пособие. Москва : Тривола, 1996. С. 24.

9. Максименко С. Д. Розвиток психіки в онтогенезі. В 2 т. Т. 1 : Теоретико-методологічні пробеми генетичної психології : монографія. Київ : Форум, 2002. С. 291.

10. Ананьев Б. Г. Избранные психологические труды : В 2-х т. Т. 1. Москва, 1970. С. 192.

11. Рыбалко Е. Ф. Возрастная и дифференциальная психология : учебное пособие. Ленинград : Изд-во Ленинградского ун-та, 1990. C. 7-10.

12. Заброцький М. М. Вікова психологія : навчальний посібник. Київ : МАУП, 1998. С. 4-5.

13. Мясоїд П. А. Загальна психологія : навчальний посібник. Київ : Либідь, 1998. С. 4.

14. Титаренко Т. М. Вікова динаміка особистісних дисгармоній. Практична психологія та соиіальна робота. 2004. № 9. С. 67-74.

15. Прахова С. А. Психологічні детермінанти подолання фрустраційних станів учнів різних вікових груп : дис. ... канд. психол. н. : 19.00.07. Київ, 2017. 241 с.

16. Лактіонова Г. М. Учнівська молодь постмодерного часу (за результатами зарубіжних досліджень). Практична психологія та сочіальна робота. 2009. № 5. С. 56-58. 
17. Чуприкова Н. И. Психология умственного развития: Принцип дифференциации : монография. Москва : Столетие, 1997. 480 с.

18. Асмолов А. Г. Психология личности: Принципы общепсихологического анализа : монография. Москва : Смысл, 2001. 416 с.

19. Князева Е. Н., Курдюмов С. П. Законы эволюции и самоорганизации сложных систем : монография. Москва : Наука, 1994. $238 \mathrm{c}$.

20. Ананьев Б. Г. Человек как предмет познания : монография. Ленинград : ЛГУ, 1968. С. 272.

\section{Information about the authors: Partyko T. B.}

$\mathrm{PhD}$ in Psychology, Associate Professor, Professor at the Department of Psychology of the Ivan Franko National University of Lviv

1, Universitetska str., Lviv, 79000, Ukraine

Snyadanko I. I.

Doctor of Psychological Sciences, Associate Professor, Head of Theoretical and Applied Psychology Department of the National University "Lviv Polytechnic" 12, Stepana Bandery str., Lviv, 79000, Ukraine

Hrabovska S. L. $\mathrm{PhD}$, Professor, Head of the Department of Psychology of the Ivan Franko National University of Lviv

1, University str., Lviv, 79000, Ukraine 